\title{
PV Integrated single-phase dynamic voltage restorer for sag voltage, voltage fluctuations and harmonics compensation
}

\author{
Toufik Toumi ${ }^{1}$, Ahmed Allali ${ }^{2}$, Othmane Abdelkhalek ${ }^{3}$, Abdallah Ben Abdelkader ${ }^{4}$, \\ Abdelmalek Meftouhi ${ }^{5}$, Mohammed Amine Soumeur ${ }^{6}$ \\ ${ }^{1,2,4,5}$ Faculty of Electrical Engineering, University of Sciences and Technology of Oran, Algeria \\ ${ }^{3,6}$ Faculty of Technology, University of Tahri Mohammed Bechar, Algeria
}

\begin{tabular}{l}
\hline \hline Article Info \\
\hline Article history: \\
Received Mar 13, 2019 \\
Revised Apr 20, 2019 \\
Accepted Jul 8, 2019 \\
\hline
\end{tabular}

\section{Keywords:}

Boost converter

Dynamic Voltage Restorer

(DVR)

Harmonics

Photovoltaic (PV)

Sliding mode control

Voltage fluctuations

Voltage sag/swell

\begin{abstract}
This document proposes a photovoltaic (PV) based single-phase dynamic voltage restoration (DVR) device, it eliminates both sag and swell voltage and compensates for power. The proposed system requires a power source to compensate for the sag/swell voltage. This system has found a simple topology for the DVR that uses PV with two DC-DC boosts converters as the DC power source for the dynamic voltage conservator. The DC/DC boost converter powered by the $\mathrm{PV}$ generator is applied to increase the voltage to meet the $\mathrm{DC}$ bus voltage requirements of the single-branch voltage source inverter (VSI). This system uses renewable energy; saves energy accordingly and supplies power to critical/sensitive loads. The control method used in this work is a Sliding Mode Control (SMC) method and relies on a phase locked loop (PLL) used to control the active filter. The effectiveness of the suggested method is confirmed by the MATLAB/Simulink ${ }^{\circledR}$ simulation results and thelaboratorial prototype. These results show the capacity of the proposed DC link control.
\end{abstract}

This is an open access article under the $\underline{C C B Y-S A}$ license.

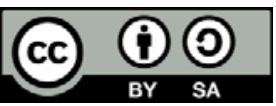

\section{Corresponding Author:}

Toufik Toumi,

Department of Electrical Engineering,

Faculty of Electrical Engineering,

University of Sciences and Technology of Oran,

BP 1505, El M'naouer, 31000, Oran, Algeria.

Email: webusto-mb@univ-usto.dz; toufiktoumi@yahoo.fr

\section{INTRODUCTION}

Industries have achieved a remarkable rate of growth in late years with sophisticated and advanced computers and equipment. A very good product quality, downsizing and financial gain from this modern industrialization method have opened the door to market for sensitive installation and control devices, automated manufacturing units and computerized process controls. The significant benefit of the revenues collected has provided these popular systems in the industrial field, whatever their initial cost. Most processes implying this device are disrupted by voltage quality issues. Industrial and residential disturbances in power quality are largely due to voltage drop, voltage swell and long delay power interruptions [1,2]. The sag voltage is determined as an abrupt decrease in the supply voltage which can go between $10 \%$ and $90 \%$ of its rated sinusoidal waveform.However although, the voltage swell is determined as an abrupt rise in source voltage between $110 \%$ and $180 \%$ of its rated sinusoidal value. In accordance with IEEE standards 519-1992 and IEEE 1159-1195, a typical time of sag and swell voltage is between $10 \mathrm{~ms}$ and $1 \mathrm{~min}$ [3-5]. The Dynamic Voltage Regulator (DVR) has become in recent years famous as a successful solution for the protection of sensitive loads with voltage sag and swells by injecting the series voltage and the synchronism with the mains supply voltage [6-10]. The DVR is connected in series with the distribution line via an injection transformer as in 
Figure 1. During a short circuit fault, the voltage on the distribution bus decreases. This causes a dip in the voltage happens in the sensitive load. To solve the voltage across the load, the DVR is aimed to this purpose. [11-13]. The DVR's power switches must be controlled using an appropriate control strategy to produce gating signals for the DVR's power switches [14-16].

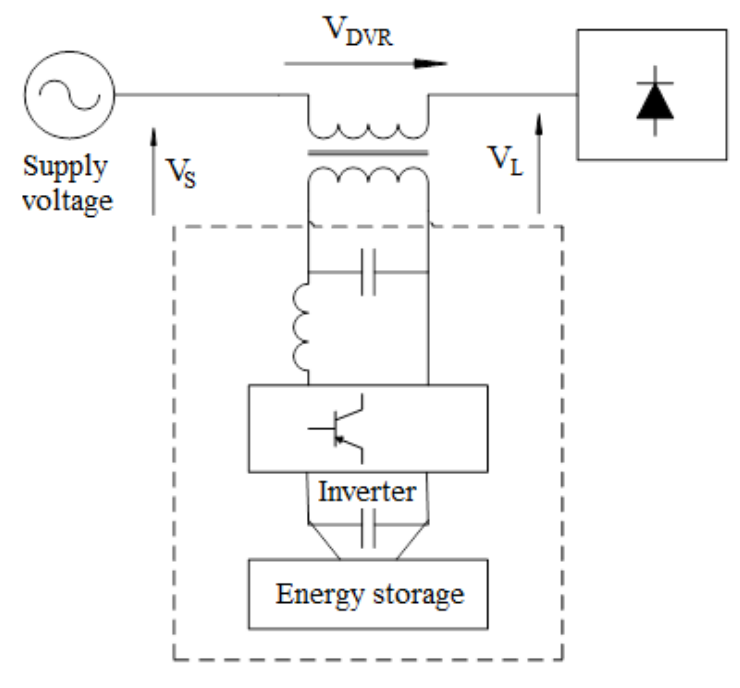

Figure 1. General DVR structure

Growing concern over growing energy consumption, environmental degradation resulting from the burning of fossil fuels and fluctuating oil prices nations have increased the use of renewable energy generation in the application of the power system. PV based DVR has device to solve the voltage power quality problems for a small industry, especially in rural areas, areas have a significant amount of sunstroke. This can happen in developing countries, where the electrical energy generated is less than their demand. The disadvantage of photovoltaic electricity production systems is that, the photovoltaic generator loses its output capacity when the radiation level is changed.

This paper presents a new topology of the PV-based dynamic voltage restorer to reduce voltage disturbances, especially sag, swell voltage and harmonic. Two DC-DC converters are used to double the voltage of the photovoltaic system and power the Voltage Source Inverter (VSI) of the dynamic voltage conservator. The MPPT algorithm based on disturbances and observation is practiced to draw maximum power from the photovoltaic system of the first DC-DC converter. a control based on two current loops to define the pulses of the second converter to keep the output voltage of the second DC-DC converter.

The document is organized as follows: The configuration of DVR powered by the PV will be presented in section 2. It also highlights the required units such as power source, linear load, DVR and control engineering algorithms. Then, the main results of the simulation,voltage waveforms and THD analyzes will be discussed in section 3. Finally, the document will be completed by the concluding remarks.

\section{DESCRIPTION SYSTEM}

\subsection{PV Integrated single-phase dynamic voltage restorer}

he dynamic voltage restorer is one of the FACTS means, which is connected in series with the distribution line via the transformer and consists of a voltage source inverter (VSI) to achieve $\mathrm{DC} / \mathrm{AC}$ conversion, a DC voltage source to supply the DC link of the VSI [17]. the main role of the DVR is maintained the magnitude voltage at a sensitive load in case of dynamic fluctuation of the voltage. The DVR corrected the voltage in the distribution system under the voltage power quality problems. The proposed power system model includes a PV system, a DVR, energy storage devices and two cascaded multilevel converters. MPPT is an essential part of a solar photovoltaic system. The (P\&O) MPPT algorithm applies a slight increment or decrement of the DV perturbation voltage to the operating voltage of the PV module. The VPV and IPV parameters measured from the PV generator output are used to generate a control signal Vref for the PWM generator. The operating principle of the $(\mathrm{P} \& \mathrm{O})$ MPPT has been explained in $[18,19]$. Photovoltaic systems

Int J Pow Elec \& Dri Syst Vol. 11, No. 1, Mar 2020 : 547 - 554 
use in the set of DC-DC converters, which are usually switching regulators to convert the DC voltage, normally unregulated, into a regulated DC voltage. In the proposed single-phase DVR, a photovoltaic generator with two DC-DC voltage boosters, the first connected with a MPPT algorithm is incorporated to work as a DC voltage source for the second converter, which is associated two regulation loops and operate as a DC voltage source for the DVR. The schematic diagram of the single-phase DVR is shown in Figure 2.

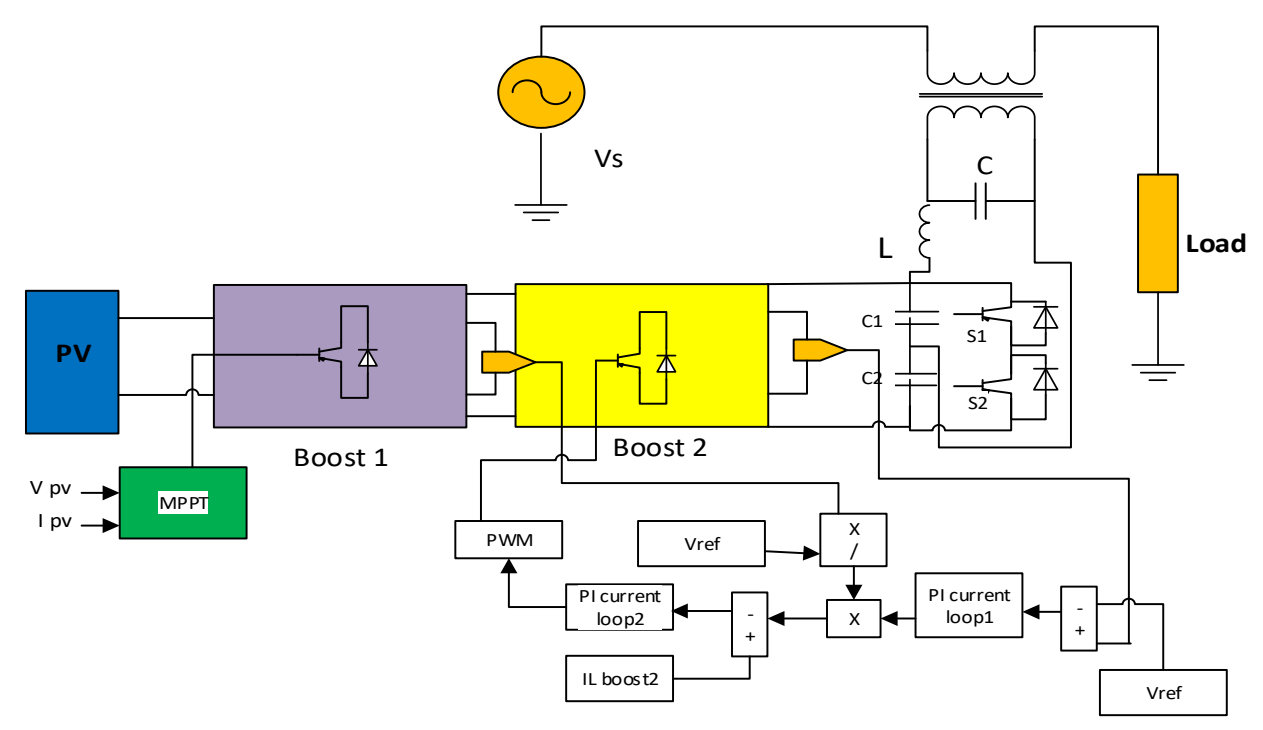

Figure 2. Configuration of PV-DVR

\subsection{PV panel model}

The solar cell formed a basic unit of a PV system. Solar cell or photovoltaic PV is a device composed of semiconductor materials such as silicon, gallium arsenide and cadmium telluride, etc., which directly converts sunlight into electricity. The voltage of a solar cell does not highly depend on the solar irradiance, but mainly depends on the temperature of the cell. PV modules can be designed to serve different voltages by assembling cells in series. Typically, a solar cell can be modelled by a single diode of PV cell [20, 21]. The PV equivalent circuit is shown in Figure 3.

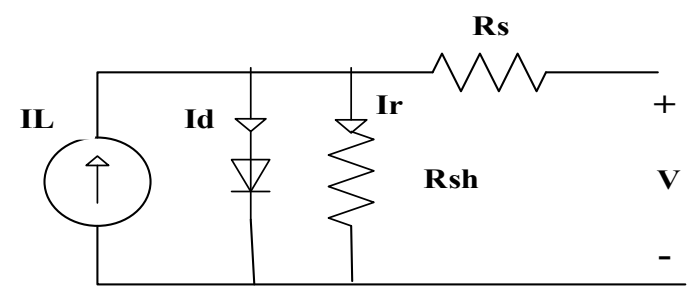

Figure 3. Single model of the PV cell

\subsection{Control algorithm for MPPT perturbation \& observation (P\&O) method}

The model of the proposed photovoltaic generator uses theoretical and empirical equations as well as data generated by the unique MPPT monitoring technique based on data at varying temperatures and by solar radiation among other variables. The $(\mathrm{P} \& \mathrm{O})$ algorithm works by periodically disturbing the operating voltage, which are based on the fact that, on the voltage-power characteristic. If the power difference $\Delta \mathrm{P}$ and the voltage difference $\Delta \mathrm{V}$, both in the positive direction, the grid voltage increases. If the voltage difference or the power difference is in the negative direction, the mains voltage decreases. If the voltage and the power difference are in the negative direction, the mains voltage increases [22, 23]. A Flowchart of the (P\&O) algorithm is found in Figure 4.

PV Integrated single-phase dynamic voltage restorer for sag voltage, voltage fluctuations ... (Toufik Toumi) 


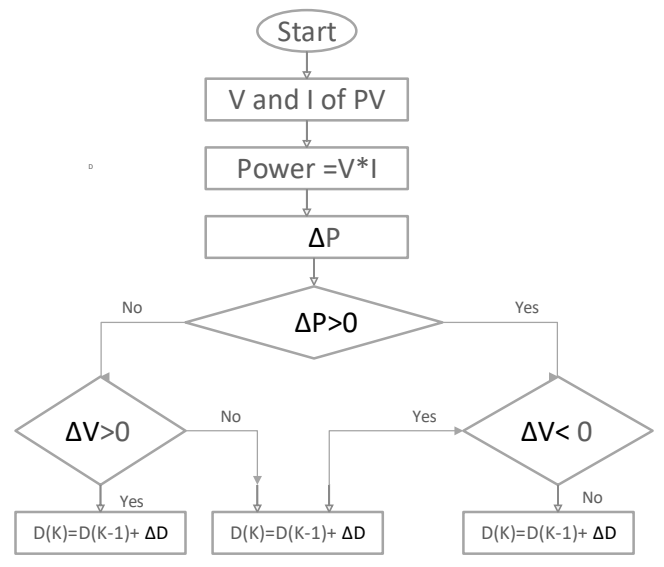

Figure 4. P\&O algorithm

\section{CONTROL SCHEME}

In the single-phase DVR, a simple control method is proposed and its efficiency at frequent instances is evaluated by simulation. The voltage dip as well as the overvoltage are simulated and compensated by an active filter in series with a Sliding Mode Control (SMC) method. In addition, a single-phase locked loop is used to extract the attitude data. The phase locked loop of this document is a good choice for such structures and the method of treatment is simple and exceptionally robust. The Sliding Mode controller processes this error to generate a reference current amplitude multiplied by a sinusoidal signal to generate a reference AC signal. The sinusoidal signal has the same phase and the same frequency as that of the network voltage and is generated by the PLL. Figure 5 shows the equivalent circuit of Single-phase DVR and block diagram of control scheme.

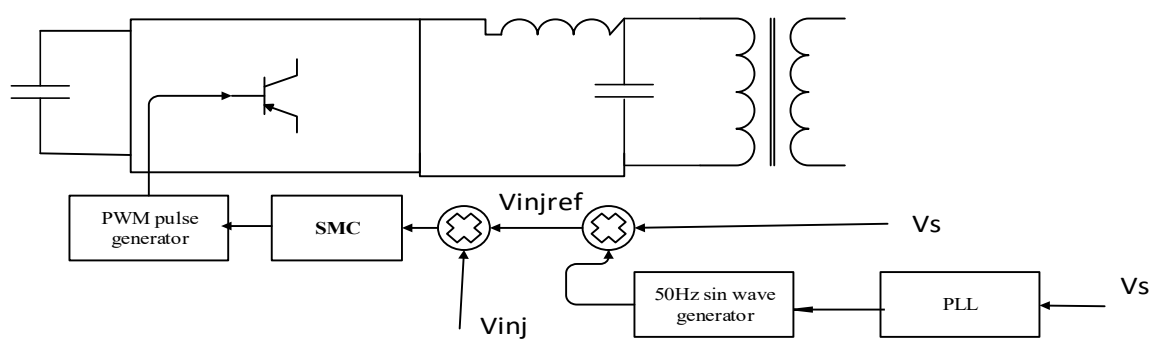

Figure 5. Equivalent circuit of Single-phase DVR and block diagram of control scheme

Principle of Sliding Control - in accordance with the general theory of sliding control, all state variables are found and the corresponding errors are multiplied by gains $\mathrm{Ki}$ and summed to form the sliding function $\Psi$. Then the hysteresis controller keeps this function close to zero so we can write: $\Psi=\sum_{i=1}^{N} K_{i} * \alpha_{i}=0$ ( $\mathrm{N}$ is number of state variables and $\alpha$ is the error in state variable) [24, 25]. Designer must perform the following three main tasks for controller design:

- Choice of sliding surface

- Check for existence of sliding mode and reaching condition

Figure 6 shows the sliding control of the DVR. In order to control, we must find the sliding surface that will be directly affected by the switching law. 


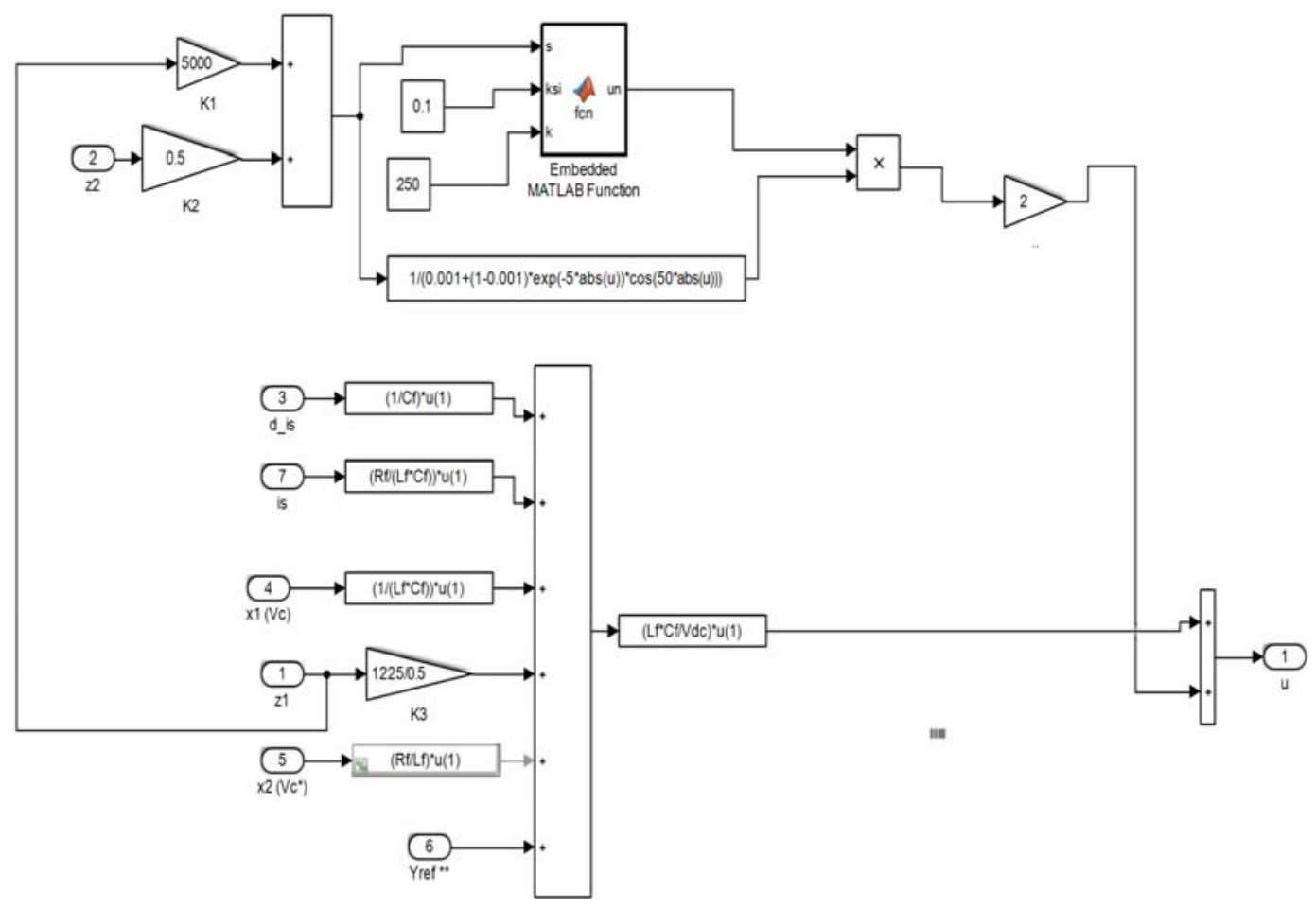

Figure 6. Sliding mode control in matlab

\section{SIMULATION RESULTS}

To verify the proper functioning of the proposed DVR powered by a PV system controlled by sliding mode,simulations were developed in MATLAB|Simulink. The parameters which have been used in the simulation are shown in Table 1 to Table 3. Sag Voltage applies between 1.2 to $2 \mathrm{~s}$, where the amplitude of the voltage is chosen equal to $50 \%$, which corresponds to $0.5 \mathrm{pu}$ in the phase. In the case of harmonics, using the programmable AC source, two main harmonics of order 5 and 7 are generated with a magnitude and an angle phase of $\left[0.2 \mathrm{pu}, 35^{\circ}\right]$ and $\left[0.3 \mathrm{pu},-25^{\circ}\right]$ respectively. At instance $t=1.2 \mathrm{~s}$, the single-phase DVR compensates for and corrects the voltage harmonics by injecting the complementary voltage value by the injection transformer. Thus, during the compensation, the total harmonic distortion value THD improved, where the source THD $=50 \%$ and the THD load $=2.93 \%$. As an observation, the PV current was not affected by the harmonics of the applied voltage. in the case of voltage fluctuation, the AC programmable source is programmed to create a voltage and frequency disturbances, where following specifications are used time variation (Amplitude) and type of variation is modulation.

Table 1. DVR system parameters in simulation

\begin{tabular}{ll}
\hline Source voltage fréquence $f$ & $50 \mathrm{~Hz}$ \\
\hline Source voltage Vs & $7 \mathrm{v} \mathrm{RMS}$ \\
Load resistance RL & $50 \Omega$ \\
CF (LC filter) & $1 \mathrm{nF}$ \\
LF (LC filter) & $24 \mathrm{mH}$ \\
Transformer & $12 \mathrm{~V} / 230 \mathrm{~V} 1 \mathrm{kVA}$ \\
dc-bus capacitor C & $33000 \mathrm{uF}$ \\
reference vdc voltage & $\mathrm{vdc}=75 \mathrm{v}$ \\
\hline
\end{tabular}

Table 2. The performance of Pv

\begin{tabular}{ll}
\hline $\mathrm{V}_{\max }$ & $19.7 \mathrm{~V}$ \\
\hline $\mathrm{I}_{\max }$ & $1.83 \mathrm{~A}$ \\
$\mathrm{~V}_{\mathrm{OC}}$ & $27.6 \mathrm{~V}$ \\
$\mathrm{IsC}_{\mathrm{SC}}$ & $2.06 \mathrm{~A}$ \\
Irradiation & $1000 \mathrm{~W} / \mathrm{m}^{2}$ \\
Temperature & $25^{0} \mathrm{c}$ \\
\hline
\end{tabular}

Table 3. Sliding mode controller parameters

\begin{tabular}{l|l}
\hline $\mathrm{A} 1$ & 5000 \\
\hline $\mathrm{A} 2$ & 0.5 \\
\hline
\end{tabular}




\subsection{Voltage sag}

Figure 7 shows the voltage sag, voltage injected by the DVR and load voltage. Figure 8 shows the DC voltage of the PV convertion chain in sag voltage case.
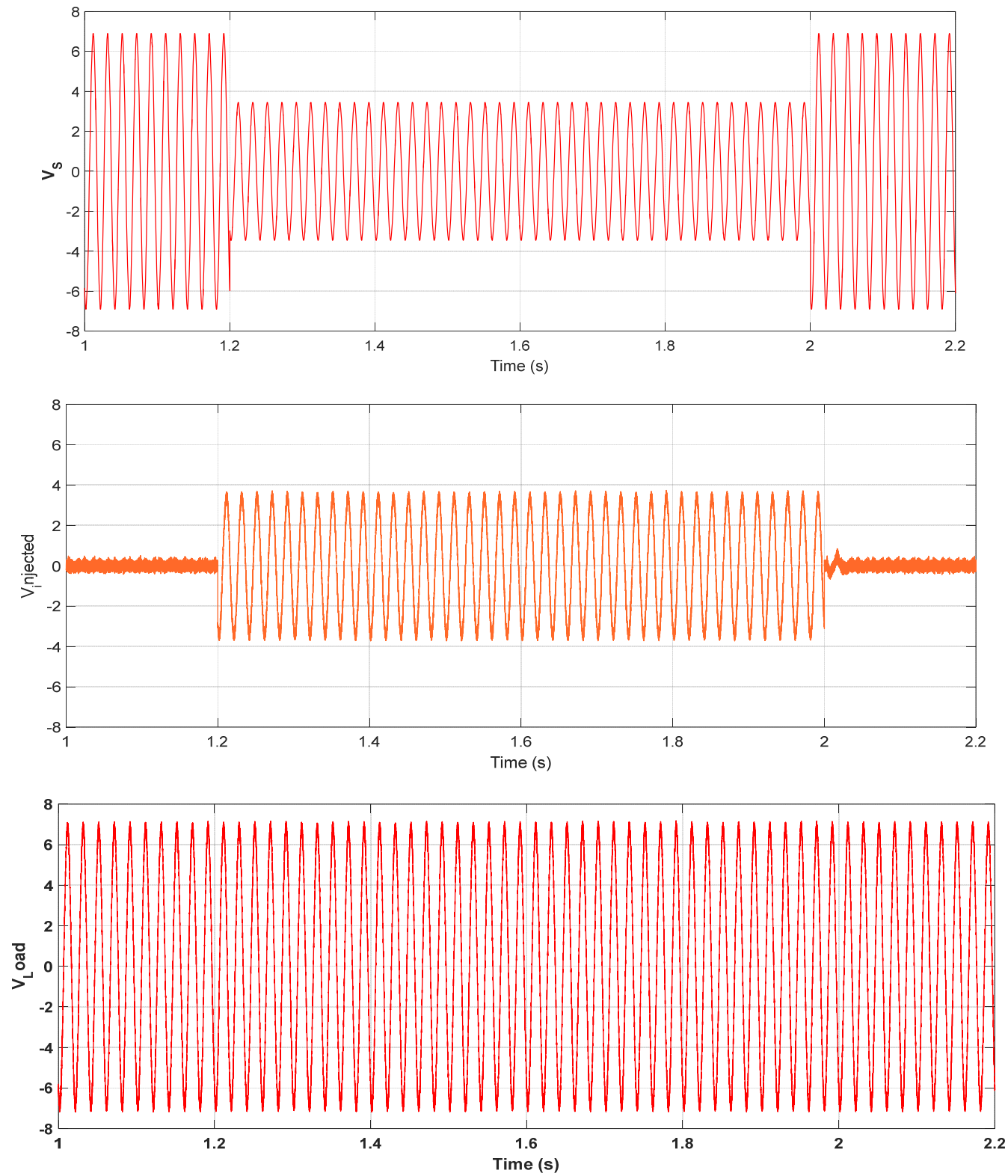

Figure 7. Voltage Sag, voltage injected and load voltage 


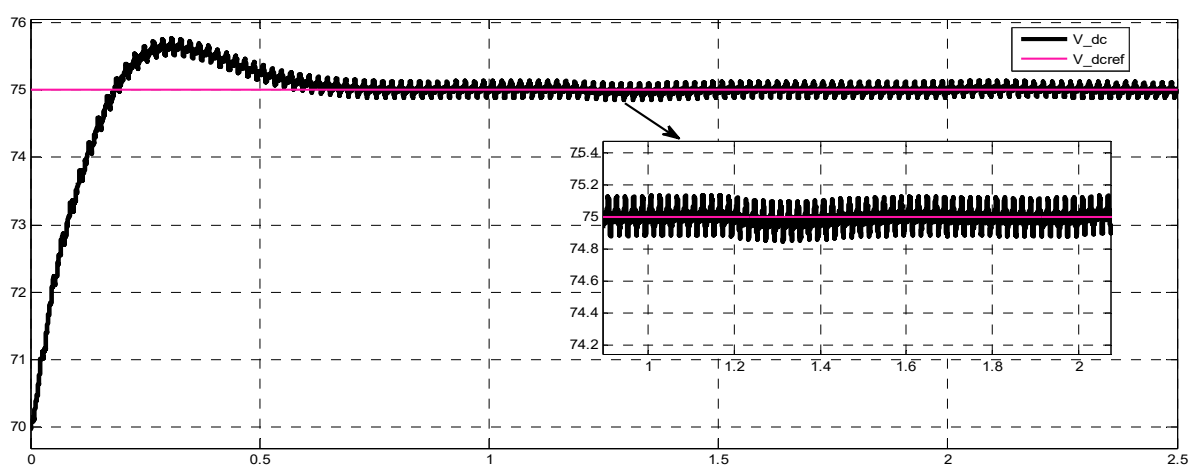

Figure 8 . DC voltage of the PV convertion chain in sag voltage case

\subsection{Harmonics elimination}

Figure 9 shows the harmonic rich voltage, voltage injected by the DVR and load voltage. Figure 10 shows the DC voltage of the PV convertion chain in Harmonic voltage case.
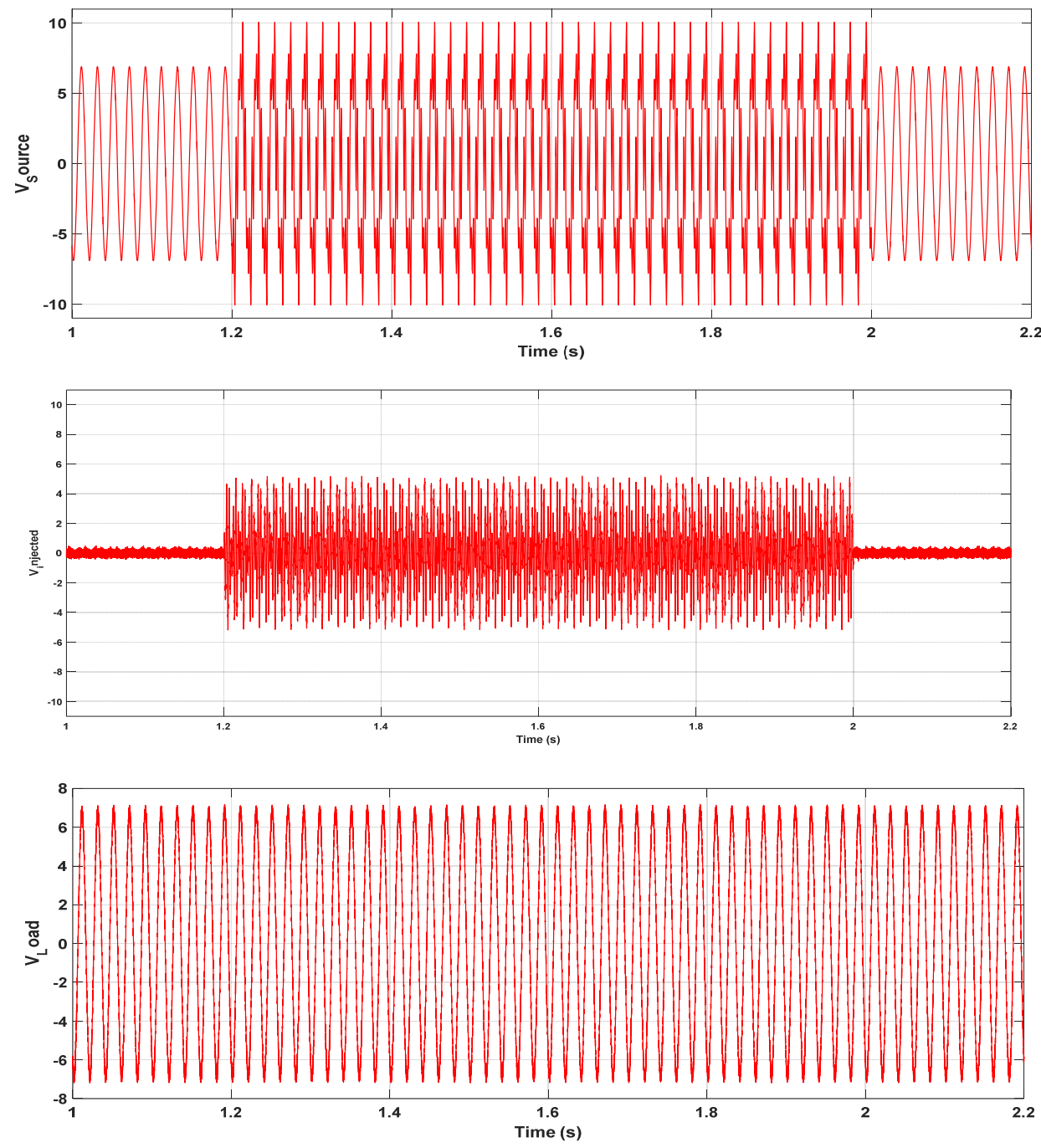

Figure 9. Harmonic rich voltage, voltage injected and load voltage

PV Integrated single-phase dynamic voltage restorer for sag voltage, voltage fluctuations ... (Toufik Toumi) 


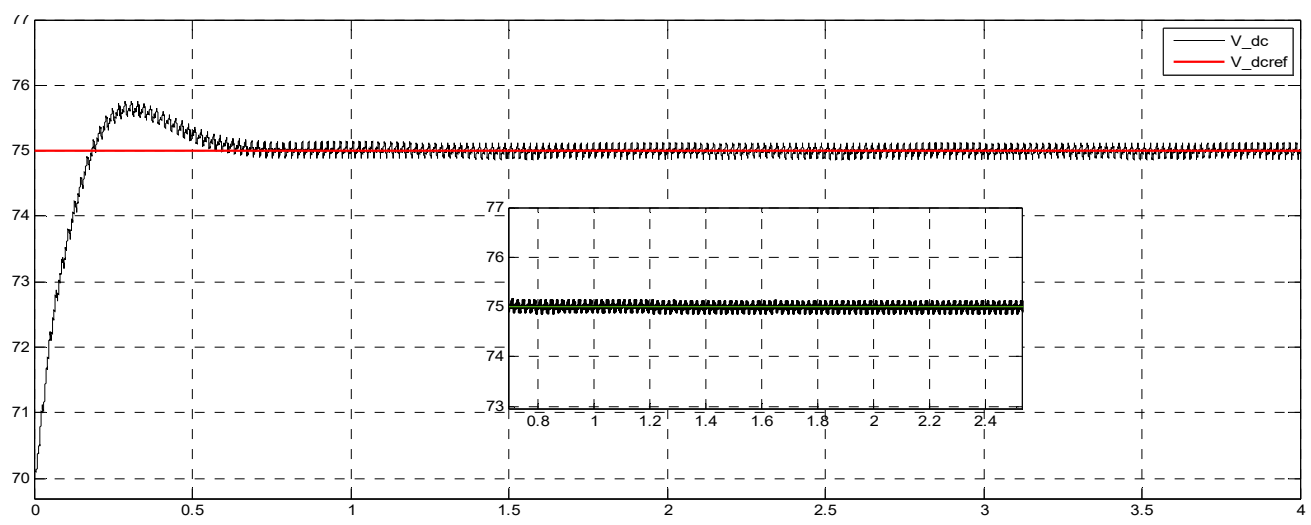

Figure 10. DC voltage of the PV convertion chain in Harmonic voltage case

\subsection{Voltage fluctuations}

Figure 11 and Figure 12 show the voltage fluctuations, voltage injected by the DVR and load voltage and DC voltage of the PV convertion chain in Voltage fluctuations case. Figure 13 and Figure 14 show the FFT of source voltage before and after using DVR-PV.
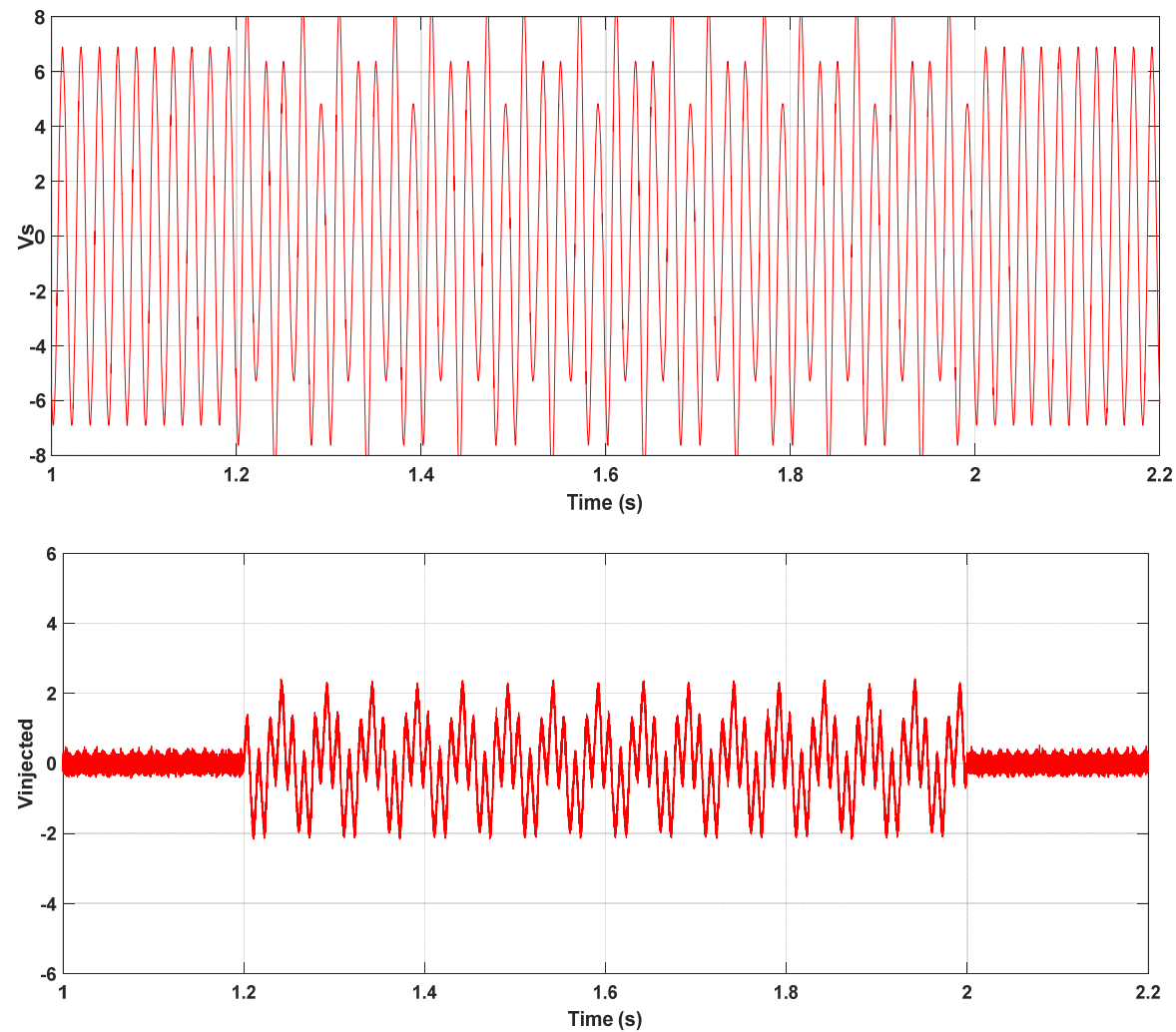

Figure 11. Voltage fluctuations, voltage injected by the DVR and load voltage 


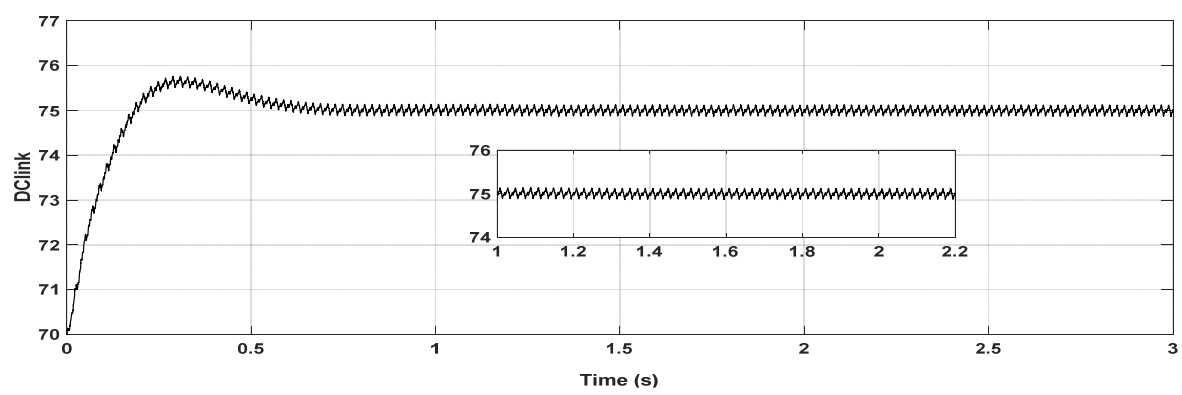

Figure 12. DC voltage of the PV convertion chain in Voltage fluctuations case

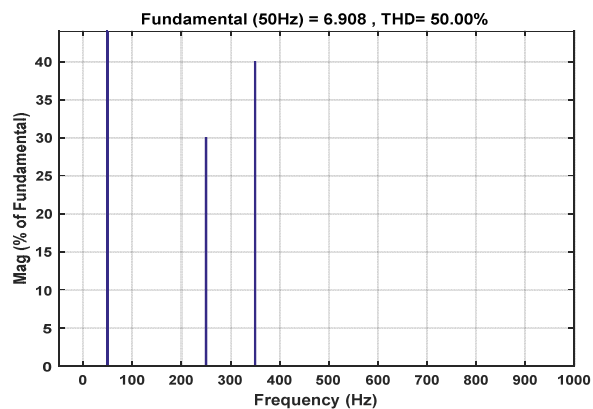

Figure 13. The FFT of source voltage befor using DVR-PV

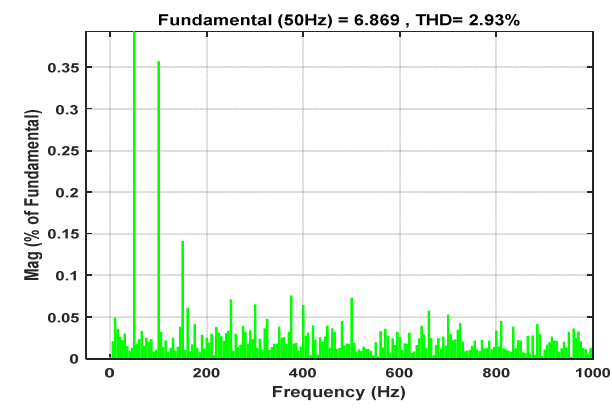

Figure 14. The FFT of source voltage after using DVR-PV

\section{CONCLUSION}

In this article, it is proposed to design and simulate a new DVR system powered by a renewable energy source. The proposed system consists two conventional up-converters for harmonic compensation, sag voltage and voltage fluctuations to the load. The PV system consists an MPPT algorithm for extracting the maximum power of the panel. The DVR system was controlled by a sliding mode controller. From the tasks performed under Matlab simulink, it can be noted that from this simulation that the THD of the source voltage is reduced from $50 \%$ to $2.96 \%$ with the DVR-PV. Among the results obtained, renewable energies can be an effective solution for solving energy quality problems.

\section{REFERENCES}

[1] Moreno-Munoz A, de-la-Rosa JJG, Lopez-Rodriguez MA, Flores-Aries JM, Bellido-Outerino FJ, Ruiz-de-Adana M., "Improvement of power quality using distributed generation," Int. J. Electr. Power Energy Syst., vol. 32(10), pp. 1069-76, 2010.

[2] W. E. Brumsickle, R.S. Schneider, G.A. Luckjiff, D.M. Divan, and M.F. McGranaghan, "Dynamic sag correctors: cost-effective industrial power line conditioning," IEEE Trans. Ind. Appl., vol. 37(1), pp. 212-217, 2001.

[3] H. Ezoji, A. Sheikholeslami, M. Tabasi, and MM. Saeednia, "Simulation of dynamic voltage restorer using hysteresis voltage control," Eur. J. Sci. Res., vol. 27, pp. 152-66, 2009.

[4] H. Ribeiro, H. Marques, and BV. Borges, "Characterizing and monitoring voltage transients as problem to sensitive loads," Int J Electr Power Energy Syst., vol. 43, pp. 1305-17, 2012.

[5] A. Honrubia-Escribano, E. Gomez-Lazaro, A. Molina-Garcia, and JA. Fuentes, "Influence of voltage dips on industrial equipment: analysis and assessment," Int J Electr Power Energy Syst., vol. 41, pp. 87-95, 2012.

[6] M. H. Bollen and M. H. Bollen, Understanding power quality problems: voltage sags and interruptions. IEEE press, New York, 2000.

[7] A. Sannino, M. G. Miller, and M. H. Bollen, "Overview of voltage sag mitigation," Power Engineering Society Winter Meeting, IEEE, pp. 2872-2878, 2000.

[8] D. J. Carnovale and T. J. Hronek, "Power quality solutions and energy savings - what is real?" Energy Engineering, vol. 106, no. 3, pp. 26-50, 2009.

[9] N. Athanasiadis. "Power quality solutions for voltage sags using dynamic voltage restorers," Electric Power Components and Systems, vol. 31, no. 2, pp. 159-170, 2003.

PV Integrated single-phase dynamic voltage restorer for sag voltage, voltage fluctuations ... (Toufik Toumi) 
[10] J. G. Nielsen, M. Newman, H. Nielsen and F. Blaabjerg, "Control and testing of a dynamic voltage restorer (DVR) at medium voltage level," IEEE Transactions on power electronics, vol. 19, no. 3, pp. 806-813, 2004.

[11] A. Ghosh and G. Ledwich, Power quality enhancement using custom power devices. London, UK: Kluwer, 2000.

[12] K. Perera, D. Salomonsson, A. Atputharajah and S. Alahakoon, "Automated control technique for a single phase dynamic voltage restorer," Proceedings of the International Conference on Information and Automation, pp. 63-68, 2006.

[13] A Benabdelkader, O Abdelkhalek, A. Allali, A. Meftouhi, and T. Toumi, "Experimental Validation of Single Phase Series Active Power Filter Using Fuzzy Control Technique," International Journal of Power Electronics and Drive Systems (IJPEDS), vol. 9, no. 2, 2018.

[14] G. Ramya, V. Ganapathy, and P. Suresh, "Power Quality Improvement Using Multi-Level Inverter Based DVR and DSTATCOM Using Neuro-Fuzzy Controller," International Journal of Power Electronics And Drive Systems (IJPEDS), Vol. 8, No. 1, pp 316-324, March 2017.

[15] B. Ferdi, S. Dib, B. Berbaoui, and R. Dehini, "Design and Simulation of Dynamic Voltage Restorer Based on Fuzzy Controller Optimized by ANFIS," International Journal of Power Electronics And Drive Systems (IJPEDS), Vol. 4, No. 2, pp 212-222, June 2014.

[16] F. B. Ajaei, S. Afsharnia, A. Kahrobaeian and S. Farhangi, "A fast and effective control scheme for the dynamic voltage restorer," IEEE transactions on power delivery, vol. 26, no. 4, pp. 2398-2406, 2011.

[17] P. Thirumoorthi, S. Deepika, and N. Yadaiah, "Solar energy based dynamic sag compensator," Green Computing Communication and Electrical Engineering (ICGCCEE), 2014 International Conference, IEEE, pp. 1-6, 2014.

[18] MA. Elgendy, B. Zahawi, and DJ. Atkinson, "Assessment of perturb and observe MPPT algorithm implementation techniques for PV pumping applications," IEEE Trans Sustain Energy, vol. 3(1), pp. 21-33, 2012.

[19] A. Meftouhi, O Abdelkhalek, A. Allali, A Benabdelkader, and T. Toumi, "PV Integrated Series Active Filter for sag voltage and harmonic Compensation,” International Journal of Power Electronics and Drive Systems (IJPEDS), vol, 10, no. 3, 2019.

[20] H. S. Rauschenbach, Solar Cell Array Design Handbook. The Principles and Technology of Photovoltaic Energy Conversion. New York: Van Nostrand Reinhold, 1980.

[21] Z. M. Salameh, and F. Dagher, "The Effect of Electrical trical Array Configuration on the Performance of a PV Powered Volumetric Water Pump," IEEE Trans. on Energy Conversion, Vol. 5, pp. 653-658, 1990.

[22] D.P. Hohm and M. E. Ropp, "Comparative Study of Maximum Power Point Tracking AlgorithmsUsing an Experimental, Programmable, Maximum Power Point Tracking Test Bed," IEEE Proc. ofphotovoltaic specialists conference, pp. 1699-1702, 2000.

[23] M. A. Elgendy, B. Zahawi, and D. J. Atkinson, "Assessment of Perturb and Observe MPPT Algorithm Implementation Techniques for PV Pumping Applications," IEEE Transaction on Sustainable Energy, Vol. 3, No. 1, pp. 2133, 2012.

[24] R.R. Errabelli, Y.Y. Kolhatkar, and S.P. Das, "Experimental investigation of DVR with sliding mode control," IEEE Power India Conference, 2006.

[25] A. Pandey, R. Agrawal, R. S. Mandloi and B. Sarkar, "Sliding Mode Control of Dynamic Voltage Restorer by Using a New Adaptive Reaching Law," Journal of the Institution of Engineers (India): Series B, vol. 98, no. 6, pp. 579-589, 2017.

Int J Pow Elec \& Dri Syst Vol. 11, No. 1, Mar 2020 : $547-554$ 